\title{
Opportunities for Biotechnology Transfer to Developing Countries
}

Don J. Durzan and M.D. Durzan

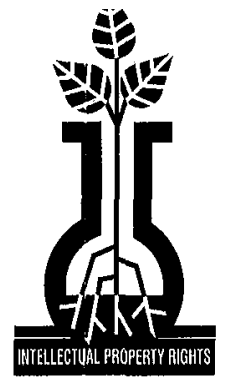

Additional index words. innovation, biotechnological impact assessment, Third-world countries, internationalization of horticultural curricula

Summary. Prospects for the establishment of joint-ventured agribusiness in developing countries are a function of international agreements, local risk conditions, business networks, and banking systems that are willing to support the innovative transfer, protection, assessment, and commercialization of biotechnology. The integration of biotechnology will occur only if truly convincing practices emerge that enhance biodiversity and the competitiveness of sustainable production, utilization, and marketing cycles. Integration also depends on agreements on intellectual property rights, plant protection, trade and tariffs, price stabilization, and nontrade-distorting policies. These policies deal with broad issues in research, pest and disease control, environmental quality, germplasm conservation, resource retirement programs, and even with crop and disaster insurance. Measures derived from these policies will apply to novel processes and to organisms that have been genetically engineered and approved for release into the environment. For developing countries, much more attention will have to be paid to biological diversity and sustainable balances among intercropped agriforest and horticultural production systems. Balances should be compatible with regional and local customs and practices before genetically engineered "green goods and services" are introduced in the marketplace. Recombinant DNA technologies are currently better-suited to deal on a "gene-by-gene" basis, with commodity surpluses and material conversions involving more concentrated and industrialized processes than with field plantations of genetically engineered, complex, and long-lived crops that may require considerable adaptive plasticity. In most countries with developing economies, the integration of recombinant DNA technology represents a "special problematique" involving politico- and socioeconomic and environmental factors. Barriers to transfer and integration may involve evolving international agreements, public acceptance, resource over-exploitation, environmental degradation, rapid insect and disease resistance, contaminated water and food supplies, reduced quality of life, labor quality, corruption, crime, farmers' rights, germplasm conservation, and lack of protection of intellectual property, among other factors. Hence, the timing and mode of transferring biotechnology needs considerable impact assessment on a case-by-case basis.

he transfer of novel horticultural technologies, goods, and ser-
vices to developing countries represents a "special problema-
tique" involving an increasingly complex and coordinated
global framework for the regulation of biotechnology. In indus-

trialized countries, most of the strategic research and development is funded by the private sector (Dibner, 1991). In developing countries where the growth rate currently exceeds that of the industrialized G-7, political instability, environmental decay, industrial inefficiency, a shortage of skilled labor, ethnic strife, and an absence of a scientific infrastructure make the adoption of biotechnology difficult. Despite abundant local 
germplasm resources, cheap wages, and potential new markets, greater cooperation and risk-sharing are needed to underwrite the costs ofinternational ventures in biotechnology. Other limiting factors are the high costs of research and development, constraints to commercialization imposed by new regulations for the release of genetically modified goods and services into the environment, intellectual property rights, and economic changes in the so-called "new world order."

We intend to show that, for opportunities in horticulture in countries with developing economies, the quality of the innovation, its market take-over time, value-added properties, and technological acceptance in local and global economies are important factors that are not yet integrated fully into current risk-assessments. For novel high-value products, the more comprehensive assessments involve impacts at the technological, environmental, economic, social, ethical, and political levels. We believe that new curricula are needed at universities in the United States to deal with past experiences and impending international problems involving all aspects of technology transfer. Fretz (1991) has identified needs associated with the internationalization of horticultural departments. We reemphasize the need for internationalization. We suggest extending it to include broader changes in institutional mandates and issues in the global environment (Zuckerman, 1992). Changes are aimed at fostering education, multidisciplinary training, global awareness, intellectual property rights, scale-up capabilities, innovative opportunities with venture capital, entrepreneurial activity, public health, and resource management at the international level. Ideally, for technology transfer to be effective, its output must be predictable, socially acceptable, environmentally sound, economically feasible, and physically possible.

\section{Horticultural innovation and its relation to agricultural biotechnology}

In the United States, many truly valuable horticultural novelties and processes are protected by the Plant Varietal Protection Act and by patent and trademark laws. A recent evaluation of the benefits of patent protection as viewed by the nursery industry is summarized in Table 1. Salquist (1987) and Wittwer (1985) have reviewed opportunities in biotechnology that relate to the seed and food industrial sectors and that deal with the "new horticulture." With forest trees and woody perennials, the traditional breeding approach has been combined with vegetative
Table 1. Some benefits and limitations of patents and trademarks in the nursery industry based on U.S. experience (see Simpson-Dolbeare, 1991). Of $\approx 7,000$ plants receiving patents since 1930, just $>300$ are landscape trees now being produced commercially in quantities of 2000 or more per year.

1) Protection is offered for the release of new, fresher, more-exciting plants, and for superior nursery stock based on prior investment, time, and effort in locating, breeding, developing, testing, and marketing the goods and services.

2) New patented cultivars may take up to a decade of the 17 years of patent protection before they are accepted in the marketplace. The "take-over time" of new goods and services can vary greatly.

3) Offering of a patented cultivar with a trademark often helps to identify new and improved cultivars and may provide more marketing potential.

4) If the patent has expired on a cultivar, the trademarked cultivar cannot be propagated, grown, and sold under the trademark without consent of the trademark owner. Royalty payments must be stipulated in a preexisting agreement.

5) Patenting helps to identify product uniformity and predictable performance for the consumer. Sometimes patents also are viewed as "tickets to the courthouse."

6) Growing patented plants without a license agreement leads to possible litigation and fines of triple royalty payments and/or removal of plants.

7) Royalties must be passed on to the originator of the cultivar; nurseries often retain some portion of royalties to offset costs in developing the market. Unfortunately, for the development of new markets, <1\% of more than 11,000 greenhouse growers have a strategic business plan (Carlson, 1992).

propagation to capture genetic gains in the broadest sense, rather than gene by gene. This helps to ensure fitness under changing environmental and climatic conditions.

All sectors of agribiotechnology are creating high-value products that are now under intensive evaluation for release into the environment (Figs. 1 and 2). These "green goods" are usually proprietary to the major processors and marketers of these products. Moreover, many of the major processors have their own breeding and genetic engineering programs for green goods and services. The strategy behind this is to keep ahead of consumer needs. Some opportunities to integrate backward and forward are identified in Table 2.

In some parts of the United States, the application of recombinant DNA methods now is becoming routine for developing valueadded plants "gene by gene" and to meet industry needs for pharmaceuticals and more flexible breeding systems. The question is not ifit can be done. Rather, the questions are different. What can be done? What impact does it have on horticulture? What can be transferred to developing countries? Can horticultural products and life-saving drugs be produced locally at prices people can afford? So far, the primary beneficiaries of biotechnology research and development have not been countries with developing economies, but the food industry (Nestle, 1992). For horticulture, permits for field testing are increasing, but there is no commercial product yet available (Fig. 2).

Given the network of International Agricultural Research Centers (IARCs), the task 


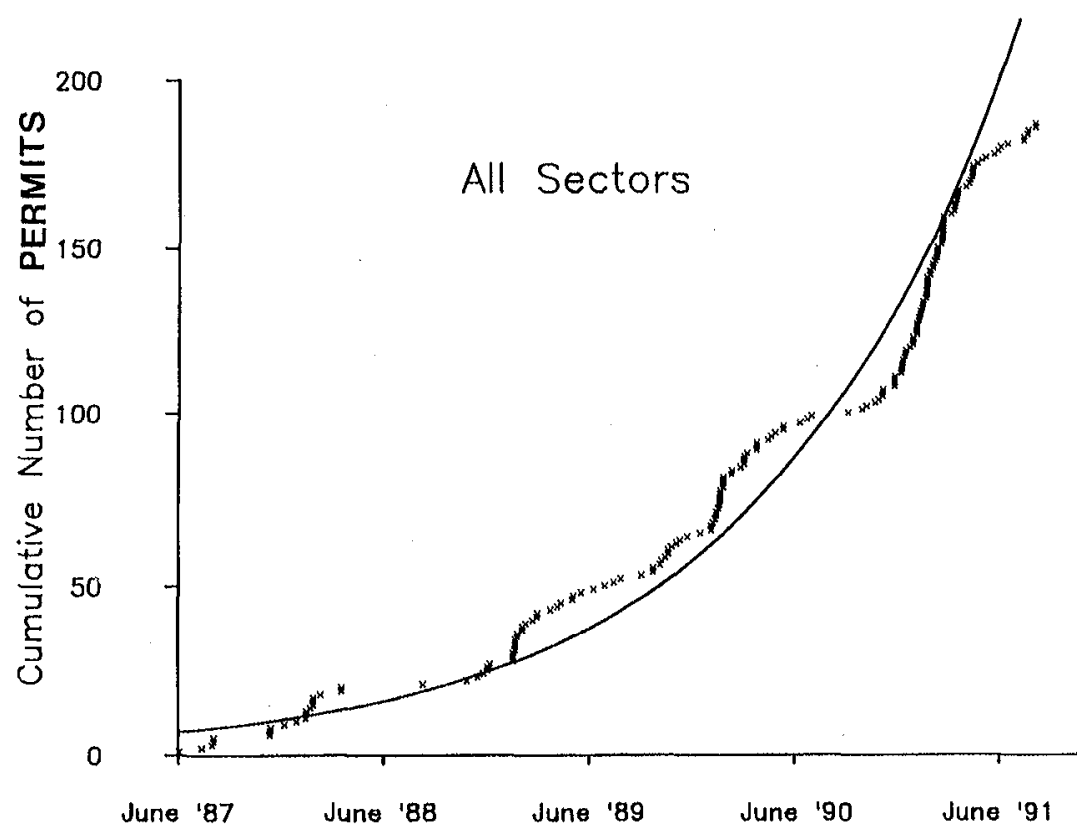

Fig. 1. The early exponential growth in permits issued to all sectors by USDA/APHIS for field-testing of transgenic plants and their release into the environment. The average cost for the preparation of an initial permit in estimated as $\$ 5000$ (Sterling, 1992).

Experimental curve (-); actual permits $(x)$.
Fig. 2. Growth in permits issued by USD $A / A P H I S$ to industry, universities, and government for field-testing of transgenic plants and their release into the environment. By Nov. 1992, more than 1000 permits to move regulated agbiotech materials from one place to another and 335 permits to field-test these materials have been issued (Sterling, 1992). Experimental curpes (-); actual permits for industry $(X)$, universities (o), and government $(\Delta)$. in biotechnology has been to realign opportunities presented by the newer genetic technologies (Fig. 3) while preserving successes of the green revolution and avoiding its mistakes (Bialy, 1991). Once these centers are free of burdening bureaucracies and are prepared to accept global intellectual property laws and common commercial rules, they should be in a position to: 1) implement the best current technology rapidly, 2) provide education and research for goods and services dependent on local conditions, 3) serve as custodians for genetic diversity, and 4) gain freer access to developed nations' markets.

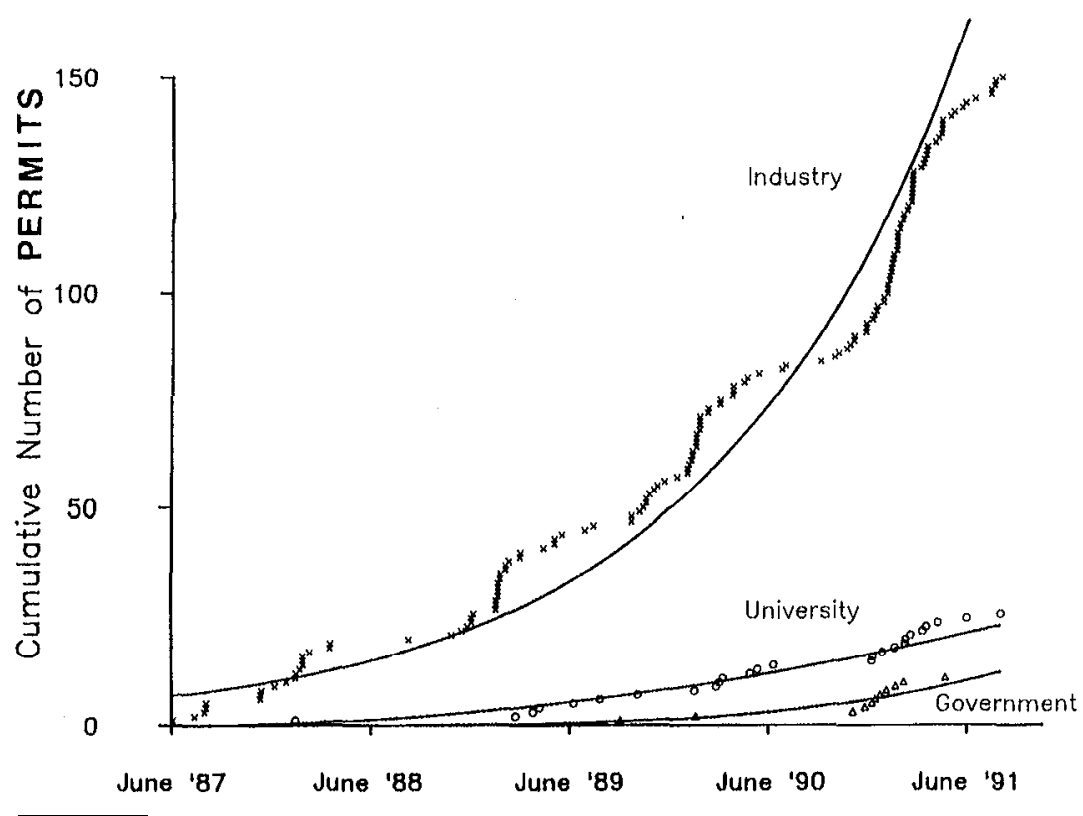

Given the current advanced state of the gene technologies and the need for success stories, we believe that most research and development will focus on improving utilization rather than production. Trends are based on innovations for pharmaceutical, specialty chemical, and food-processing industries, especially where chemists cannot yet do a better job. Historically, the only major products to be commercialized through modern biotechnology have been pharmaceutical. This trend is expected to continue (Cometta, 1989). Indeed, the number of biotechnology derived medicines in development has grown by some 63\% since 1988 (Pharmaceutical Manufacturers Assn., 1991b). This data does not yet include pharmaceuticals from horticultural products (Table 3).

We believe that horticultural applications based on biotechnology will lag because of: 1) a general lack of focus towards biotechnology; 2) the complexity of the scientific, technical, environmental, social, economic, and political difficulties involved; 3 ) the unsettled regulatory situation, including issues related to general agreements on trade and tariffs; 4) lack of public acceptance of the release of genetically engineered organisms into the environment; 5) low value-added economics of many product lines; 6) difficulty of generating products that can compete with chemicals and health-care products on a price-performance basis; and 7) delays in forming coalitions to foster research, marketing, and exports.

Great benefits to horticulture undoubtedly will derive from plant domestication, breeding, and improvement using the new diagnostic methods for genetic characterization and genome mapping. Once an improved population can be cloned reliably, the application of recombinant DNA may be employed to further "engineer" improvements, although this alone does not guarantee that it will have an impact on the market place. Figures 1 and 2, based on APHIS field trials (1987-1991), give an indication of the explosive activity in this area. Transgenic plants in these trials may offer enhanced insect and disease resistance, color, flavor, shipping quality, etc. Field trials also aim to show the acceptability of genetically modified organisms for release into the environment. The longterm behavior and stability of transgenic types under field conditions still remain to be evaluated fully before opportunities for technology transfer to developing countries can be put into perspective.

\section{Technology transfer to developing economies}

Technology transfer has been interpreted 
in terms of the myths and realities of U.S. competitiveness (Krugman, 1991). International opportunities depend on the strength of the domestic industry, the pool of skilled labor, and supplier and knowledge bases that are all self-reinforcing. The United States is still first in the commercial exploitation of biotechnology. However, progress in the development and marketing of new products has been slower than expected, largely due to: 1) the slowly emerging regulatory environment (OTA, 1991), and 2) concerns about the transfer to developing countries of intellectual property of potential industrial value.

For horticultural markets, according to the Economic Research Service (USDA), farm cash receipts in 1990 for nursery/greenhouse crops were $\$ 7.8$ billion (wholesale). This represents $10 \%$ of all farm cash receipts in the United States. Consumer expenditures for the retail/landscape sector accounted for $\$ 33$ billion. The average growth rate of the industry is currently $10 \%$ annually. This matches the growth of the fastest developing component of the world's economy; namely, the growth of international trade (Nature, 1992).

In the regulatory environment of the current world economy, there are great opportunities for the U.S. horticulture industry (Fig. 4) to work and invest at the international level. The opportunities for ornamental horticulture have been identified recently by Glass and Lindemann (1992).

Europe poses the greatest challenge to U.S. competitiveness in agricultural biotechnology (OTA, 1991). For example, technology transfer based on micropropagation offers growers and breeders the production of a superior product in less time under diseasefree conditions and regardless of many existing conditions. Modular and transportable ready-to-use laboratories are now available for export anywhere in the world. These units, offered to growers and researchers, can be operational within 6 months of placing an order. The Hortimic units (Biotechnology Division, Kemira Oy, Helsinki, Finland) are complete with all laboratory equipment, and training is provided for smooth start-up and the efficient use of micropropagation. Moreover, Hortimic licenses its own cultivars with the modular laboratory for certain new markets. This is an example of the European trend towards marketing complete units and of using licensing as a rapid means of getting into business. Proximity to countries with developing economies and to the Confederation of Independent States offers new opportunities for technology transfer.

Risks associated with biotechnology transfer to countries with developing economies are nevertheless very real (see Table 4, and Shared Risks and Cooperation). If any
Table 2. Some projected needs for: A) highly industrialized economies, and B) developing countries. Selected general goals to enhance applications of biotechnology in both situations are listed under $C$.

A. Needs for Highly Industrialized Economies by 2000

1) Find alternative sources of renewable and nonrenewable raw materials and energy. If unavailable, develop strategies for material and energy substitutions with international centers that cover key regions for cooperation, production, and utilization.

2) Overcome limitations due to local losses in biodiversity and endangered species, without compromise to future generations.

3) Decrease dependencies on water, energy, and chemicals, and increase understanding of climatic change and adaptive phenotypic plasticity.

4) Develop novel products, processes, and services that are acceptable in the marketplace.

5) Minimize or remove toxic by-products and wastes in production, utilization, and consumer cycles, especially in mega-cities.

6) Ensure greater protection for intellectual property and germplasm without promises that are hedged with qualifications that exceed immediate gifts of money.

\section{B. Needs in Developing Countries}

1) Reduce illiteracy, starvation, poverty, and disease.

2) Identify major problems to be solved and new markets in terms of land use, roads, telecommunications, renewable and nonrenewable strategic resources, availability of labor, distribution of wealth, and social insurance for the old.

3) Develop new diverse products and processes to solve and, where possible, anticipate problems. Respect rights to their own natural resources. Share in whatever profits industrialized countries expect from investments.

4) Evaluate opportunities to enhance market development by buying into or trading off local goods and services. Compensation for withholding of exploitation based on environmental reasons.

5) Work with existing institutions and agencies to train the highly qualified and skilled workers, scientists, engineers, entrepreneurs, and managers to enhance innovation.

6) Develop environmental, technological, economic, and social impact assessments for biotechnology to aid decisionmakers in the short and long terms. Encourage participatory self-determination for future developments and selfreliant national cultures.

\section{General Goals to Enhance Applications of Biotechnology}

1) Develop more cultivars for sustainable cultivation from less genetic diversity. This can be used to reduce urban and suburban decay. Avoid economic colonization in poorly industrialized countries.

2) Establish broad-ranged quality controls for existing and future horticultural goods and services.

3) Reduce failures in clonal production and utilization cycles, especially for perennial crops.

4) Enhance, where possible, the quality of life and land use in local communities, even in the context of gradual global climatic changes.

5) Develop the appropriate balance for internationalization of the biotechnology industry. Consider mergers and collaborations.

6) Target product improvements; environmentally beneficial products anticipate world markets in the short and long term.

7) Reselect or adapt exotic germplasm to specific conditions in each production area.

8) Establish roles of analytical methods (e.g., RAPDs, RFLPs) for varietal identification and define jargon (e.g., "minimal distance" and "essentially derived") in legal terms.

advantage is to accrue to U.S. companies that invest in biotechnology, breakthroughs and patents must not be pirated. Otherwise, re- 


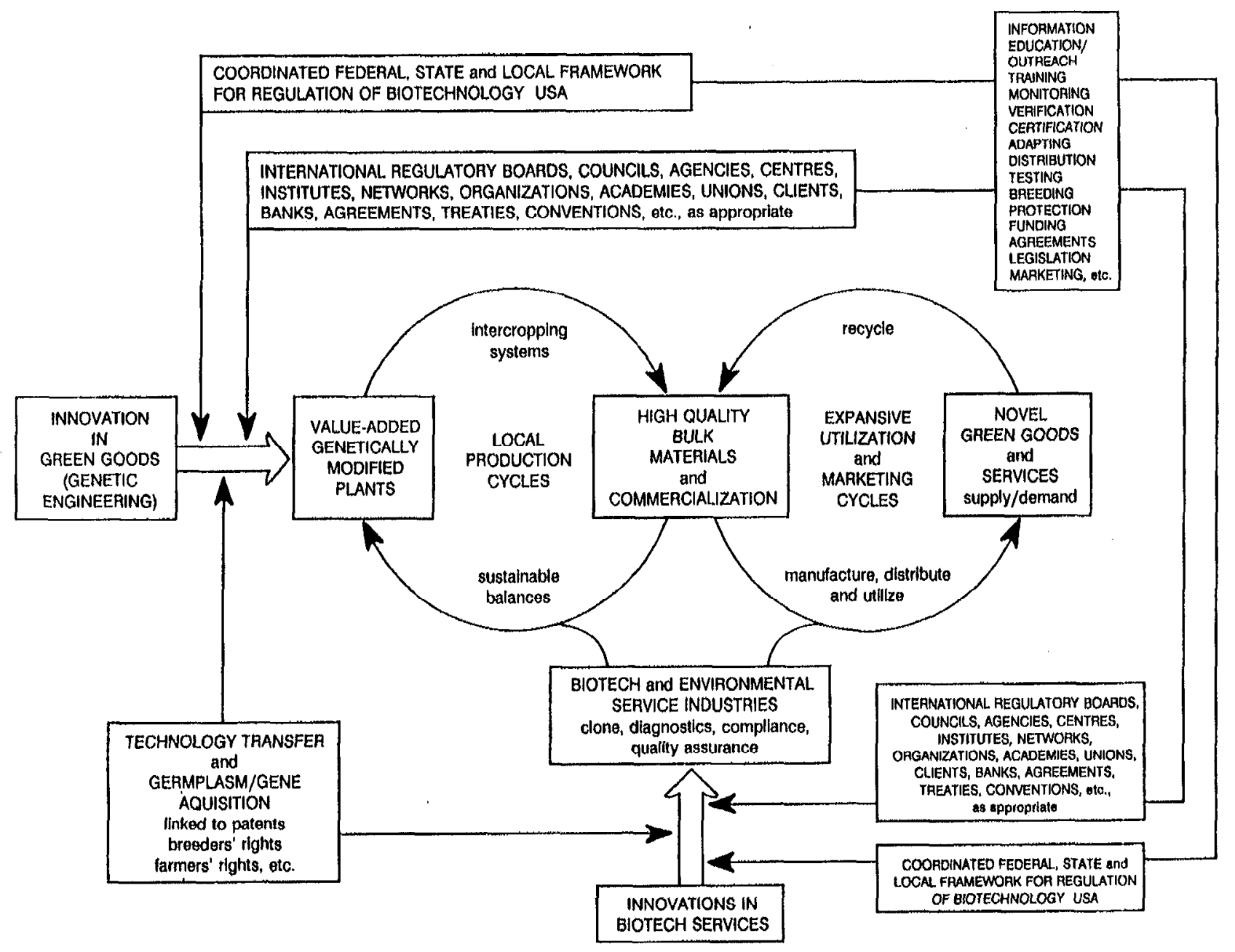

Fig. 3. A simplified network of possible interactions based on innovations in plant germplasm (genetic engineering) and biotech services (emevging industries) leading to new production and utilization cycles in agriculture. Technology transfer and germplasm/gene acquisition from the United States to countries with developing economies currently involves approval for velease of the genetically modified organism into the environment by a coordinated federal, state, and local framework that regulates biotechnology. The combined outputs of the production and utilization cycles are novel green goods and services in the market place. turns on the investment and incentives to invest will be undercut.

\section{Quality of the innovation}

Entrepreneurs in biotechnology are strongly financially and market-oriented. Through strategic planning and establishing priorities, they aim to balance high risk with low risk, short with medium term, and the costs and duration of research with consumer acceptance and the future state of the market. Questions are asked, such as: How much money will we have to spend on promotion? Who are the competitors? How are we going to develop our products? What are the regulatory endpoints? How long before our product or service will take over in the market place? Will the poor countries gain freer access to markets in countries with highly developed economies?, etc.

For the Flavr Savr tomato, Calgene spent $\$ 20$ million over 8 years to engineer long shelf-life. The early expectation was that the tomato would capture $15 \%$ of the $\$ 3.5$ billion annual market, but it would have cost consumers twice as much as a regular tomato (Nestle, 1992). Recent indications are that this tomato will not reach consumers in the near future. Because of opposition (Hoyle, 1993), Calgene now has asked the Food and Drug Administration for a more lengthy review of the kanamycin resistance gene in the Flavr Savr tomato under the stringent foodadditive provisions of the 1938 Federal Food, Drug and Cosmetics Act.

Assuming that the current permits for the APHIS field trials will be granted, it is clear that the value-added plants currently being tested are aimed at the domestic, luxury, and upscale markets. So far, these products have little direct impact on the immediate needs of the U.S. nursery industry, but the potential for further applications may be very great (Table 3). Some limitations to progress in establishing new markets could be removed by considering opportunities in countries with developing economies, provided that regulations are in place and the products are affordable and acceptable. Related to these opportunities are the fundamental issues of control, ownership, and access to biological diversity. At present, developing nations are being forced into adopting intellectual property regimes that may be inappropriate for their needs and level of develop- 
ment (Shand, 1993).

For advancing horticulture in countries with an emerging capability in biotechnology, the establishment of flexible breeding systems leading to greater genotypic diversity, product fitness, and phenotypic plasticity is needed. For perennial crops, production cycles should include intercropped agroforestry systems. Sustainable cycles offer more attraction, efficiency, and economy. In some economic sectors, the problem is oversupply of a horticultural commodity. This means that reliable biotechnologies that contribute to the conversion of surpluses to useful goods and/or services and to product substitution will become critical for further life-support and enhancement of the quality of life. Here the emphasis shifts in the application of biotechnology from production to the utilization and marketing cycles.

For innovation to continue, the following changes will be needed: 1) new legislation, policy development at local and international levels, and international trade and tariff agreements need to be devised, negotiated, and brokered on the basis of mutual interest; 2) greater scientific infrastructure and educational opportunities that foster technology transfer; 3) scale-up and pilot tests of valueadded goods released into the environment and the provision of services that facilitate compliance with regulations and sustainable agricultural and silvicultural practices; 4) greater entrepreneurial activity, changing banking objectives, risk-sharing; 5) effective managerial skills for international agencies, complex partnerships, and technology transfer; 6) new nations with potential access to huge consumer markets of highly industrialized countries need to act in accordance with international law and capitalistic economic practices.

A recent example of the development of a highly value-added product from horticultural and forestry sources is the discovery of a promising anticancer drug, taxol. This compound, the worth of which is estimated at $\$ 1$ million $/ \mathrm{kg}$, is found largely in the thin bark of the Pacific yew (Taxus brevifolia) and in some yews marketed by the U.S. nursery industry. The current supply of the drug is limited greatly by its low concentration and its occurrence in some endangered and slowgrowing trees. The demand for taxol is exceedingly high and is based on successful clinical trials sponsored by the National Cancer Institute. Bristol-Myers, Squibb has bought the rights to commercialize this drug, and considerable research activity is now underway to find ways to increase the supply of the drug. As yet, chemists cannot synthesize taxol from simple precursors. They have enlisted computers recently to aid in the design
Table 3. Challenges for the domestic nursery industry (Pacific Coast Nurseryman and Garden Supply Dealer, 1991a) and priority areas for research and development in horticultural science (Faust, 1986)

Nursery Industry

- Greater product quality and adaptive plasticity

-Larger-sized plants for "instant gratification"

- Provision of maintenance services

-Water availability, costs, and conservation measures

-Compliance to governmental regulations

-Rising land values constraining space

-Labor problems and shrinking supply of entry-level workers

-Ecological and environmental concerns, biodegradable products

-Reduced energy, fertilizer, nutrient runoff, and pesticide use

-Reliance on predators for biological control

-Superior technology and marketing

-Cooperative, mass-merchandizing

-Keeping pace with consumer needs

- Changes in product mixes and better product selection

-Reliance on more export sales

-Improved cultivars with "brand names"

-Colorful plants for xeriscaping or meriscaping

- Container garden products

-Interiorscaping products

Horticultural Science: Important Science Areas for Investigation

-Environmental stress

-Developing more flexible breeding strategies

- Genetic diversity

-Market and nutritional quality

-Postharvest quality maintenance

-Improving human environment with plants

-Biological stress

-Integrated crop management

-Growth regulators

of new structures, prodrugs, and mechanisms that mimic effects of taxol and overcome problems of therapeutics.

Other strategies involving biotechnology also are being applied in an attempt to increase the supply of this drug. The mostpromising are partial synthesis and extraction from natural sources. Even the collection of trimmings from Taxus sp., grown for ornamental use, is being organized by nurseries as a means of providing a supply of taxol (Borman, 1991). The application of recombinant DNA methods to engineer greater taxol production is untested, and is considered too long-term and complex a challenge. Technology is available, however, to clone Taxus sp. by rooting of cuttings (see Zobel, 1992), micropropagation, and by somatic embryogenesis and polyembryogenesis (Durzan, 1991). Ultimately, if advances in chemical syntheses are not forthcoming (see Amato, 1992), new cell lines from taxolproductive trees may be developed for taxol production in bioreactors, provided that this process is cost-effective.

The taxol case has raised new issues in technology transfer based on the Federal 


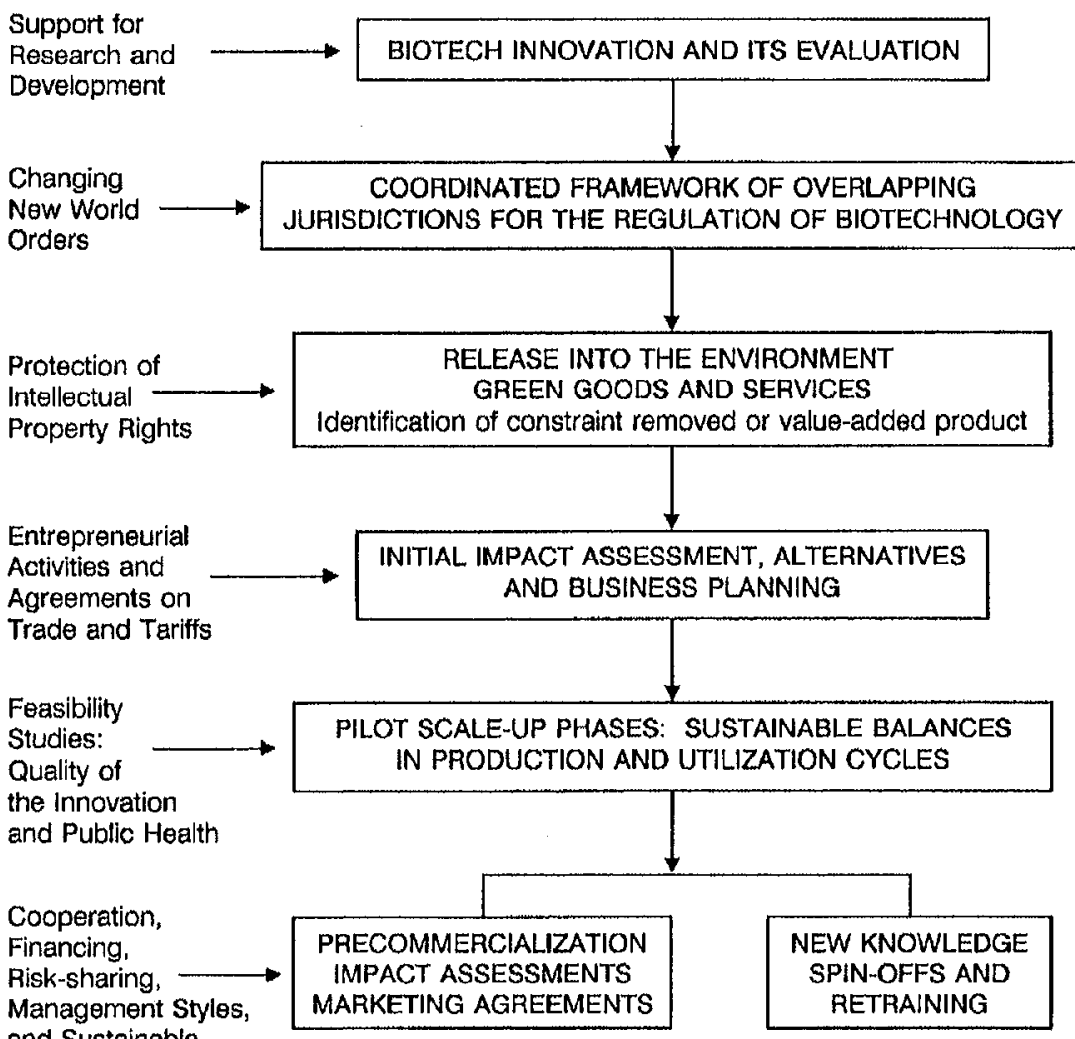

and Sustainable

Development

Fig. 4. Selected issues and steps in the assessment of a biotechnology. The release of genetically modified and cloned crops into the environ ment will affect all types of policies (Persley, 1990a, 1990b). The commercialization of green-goods and services requive an early assessment involving all of the impacted partners in a sequence shown in Fig. 3. Assessments ideally should be done at many levels: feasibility, environmental, social, economic, ethical, political.
Technology Transfer Act of 1986. This act provides a unique mechanism by which government and the private sector may cooperate as partners in product development. The mechanism is called Collaborative Research and Development Agreement (CRADA).

Questions raised by this approach are: Was the public adequately protected from price gouging in the CRADA agreement? Do the CRADA and memorandum of understanding give the industry a lock on an important new drug in an anticompetitive way? Would the public be equally well-served, or better-served, by the sharing of the National Cancer Institute's taxol data with multiple commercial partners (Chabner, 1991)? How can universities contribute to the development of this important drug?

Other examples of novel drugs, goods, and services from horticulture and economic botany undoubtedly will emerge and involve countries with developing economics. The lesser-known germplasm in these countries offers a potentially useful resource base for further activity (e.g., Vietmeyer, 1986).

\section{Integration of biotechnology}

There are many channels for biotechnology to find its way into the new world order. Transfer and integration can be achieved with the help of governmental agencies (e.g., U.S. Agency for International Development, World Bank Consultative Group, or International Agriculture Research) and multinational corporations, internal personnel transfer, or the acquisition of a foreign subsidiary. Technology brokerage organizations also have proliferated (Bakewell, 1992). New companies are thought to survive only by acquiring a sufficient number of patents; e.g., at least 125/ year. Foreign student exchange programs, career fellowships (Toenniessen, 1992), foreign aid, sales of transgenic germplasm, and technology with maintenance manuals, industrial shows, exhibits, and trade fairs are other possibilities to encourage integration. Generally, however, technical meetings, patents, and open literature are the most common sources ofinformation. The most useful way of integrating biotechnology is by a case study involving a historical analysis of related past events (Wittwer, 1985).

Good integrative practices in biotechnology are straightforward; e.g., easy access to information by individuals; free flow of information both in and out of an organization; rewards for sharing, seeking, and using new information; rewards for risk taking and for accepting and adapting to change; and encouragement of mobility and interpersonal contacts with countries requiring assistance. These practices may not always be applied successfully. It should not always be a matter of the source of the ideas. Outside ideas and technologies can cost less than those conceived and invented by a country's own scientists, but they need to match the needs of the poorly industrialized economies. In this context, the international agricultural research centers can play an important role in controlling technology transfer and assessment (Persley, 1990a, 1990b).

Where horticulture is involved, Grierson (1991) has indicated several crucial factors in technology transfer and integration. Strategies and technologies are needed to: 1) keep the crop alive at harvest until it is consumed or processed; 2) involve horticulturists at both the pre- and postharvest phases; 3 ) have experts with economic, accounting, and marketing training; 4) develop scaled-down technologies appropriate to local labor, machinery, and transportation; and 5) prepare growers psychologically to complete their projects and ventures successfully.

For successful integration to occur, we have to recognize that 1 ) there is a difference between national and international interests; 2) differences exist between national and global environmental problems; 3) long-term and short-term social and environmental issues do not belong in the same category; 4) development in the poorer countries tends 
to bring financial, managerial, and new environmental problems; and 5) solutions to most environmental problems belong mainly to the political and economic domains (Zuckerman, 1992).

\section{Intellectual property rights}

Innovations emerging from the coordinated Federal Regulatory Processes in the United States are seen as a novel source for green goods and services with applications to countries with developing economies. Protection of intellectual property is available through seed and breed certification, plant patents, and cultivar protection, and patents dealing with inventions, utility and design, copyrights, and trade secrecy (Butts, 1987). The World Bank has prepared a discussion paper on strengthening the protection of intellectual properties in developing countries (Seibeck, 1990).

Unfortunately, the costs for patenting in the United States have escalated, and the pipelines are full and subject to reform (Flam, 1993; Marshall, 1991). Even among highly industrialized economies, international patent laws vary considerably. For example, in Japan, the first to disclose, rather than the first to invent, is a criterion. Most countries are party to at least one inter-nation agreement (Persley, 1990a). Controversy continues on patenting life and life-giving forms such as genes (Anderson, 1991). Japanese scientists do not plan to join the United States and the United Kingdom in filing patents on their gene discoveries. Instead, it is claimed that they plan to publish the data and make it more freely available (Swinbanks, 1992). For poorly industrialized economies and newly emerging economic units, there is a need for more uniform and enforceable patent protection, and many products and processes are excluded from protection. [Protection would raise the cost of medical treatment and exclude the masses of poor people. Countries such as Brazil, India, and the Philippines present a challenge to the newly developed "for profit" drugs from the highly developed countries. In these three countries, pirating of drugs is currently an accepted practice.] Pharmaceuticals are excluded by 28 of 81 countries and living organisms are excluded by 30 of 81 . Moreover, the patent terms vary from 5 to 20 years (Lesser, 1990).

A case has been made that Third-world economies are being threatened by biotechnology (Shand, 1993). International tension over the ownership of genetic resources will intensify as developing nations recognize that the Biodiversity Convention excludes ex situ gene bank material collected before enactment of the Biodiversity Treaty. This means that: 1) most of the germplasm collected from tropical and subtropical countries will remain outside the agreement, and 2) a compensation package may need to be renegotiated; otherwise, access to germplasm resources will continue to be subject to embargo and dispute (Shand, 1993).

Non-trade-distorting policies that have an impact on biotechnology continue to be negotiated through the General Agreement on Trade and Tariffs (GATT). GATT operates by consensus. It has no extraterritorial authority, no world court of trade, and its members include nations that practice markedly different brands of capitalism (Kuttner, 1992).

Trade-related intellectual property rights that lead to royalty payments by countries with developing economies to the innovators in industrialized countries are currently supported by the United States and Japan. Knight (1989) has made the case that, given a favorable regulatory climate, genetic techniques will help plant breeders create new useful fruit and vegetable crops.

Attempts to patent genes and various biotechnological processes have encroached on existing international practices and rights (Kloppenburg, 1988). Plant breeders' rights have been criticized on the grounds that they: 1) allow multinational corporations to gain control of plant breeding, 2) encourage increased genetic uniformity and limit the development of new cultivars, and 3) would have a negative input on new breeding initiatives in developing countries. Hobbelink (1989) proposes strengthening the indigenous biotechnological capacity in develop-

Table 4. Some issues requiring governmental resolution for biotechnology transfer to countries with developing economies (modified from Barton, 1989; Trigo and Jaffe, 1990).

1) Enforcement of laws giving protection to foreign patents.

2) Absence of regulatory structures for environmental release of genetically modified organisms. Costs for establishing local review systems and certified product streams in an accountable way. Local adoption of U.S. regulations for import goods.

3) Low government expenditure and difficulty in obtaining hard currency.

4) Adequate price structure to support economies based on new goods and services. Provision of protection against world agricultural price distortions, especially for purchased energy.

5) Maintenance of local services, seed distribution, extension, training, public education, biosafety, ethics, and investment.

6) Mandatory public access to information, and participation in national regulatory program for impact assessment and environmental release.

7) Policies on the restriction and flow of information and germplasm when intellectual property rights are used as non-tariff barriers.

8) Protection for local farmers' and breeders' rights.

9) Agricultural practices that take land away from forestry and vice-versa.

10) Side-effects caused by public investment, crowding of people, decline of percapita consumption, and changes in security ofproperty and resources arising from consumption patterns. 
ing countries by establishing national biotechnology programs, ensuring access to germplasm, and enlisting the assistance of international non-governmental organizations (Table 4). All of this involves value judgments that are aimed at limiting the negative aspects of biotechnology and the protection of various rights. The impact of biotechnology becomes a significant factor in technology transfer if it creates concerns and controversy in the public and professional communities and has international welfare implications.

\section{Field trials and accountability to the public}

Protection offered by intellectual property laws can turn equally into a liability for technologies having poorly conceived inceptions and applications. Litigation based on common laws and natural justice has the feature of quelling unwholesome urges for quick and spectacular applications in biotechnology. Effective protection should be available for applications in developing countries and all affected individuals.

A recent field test in Hawaii identified what was already known regarding the remarkable adaptive ability of insects (Gerhold et al., 1966; Gould, 1991). Diamondback moths have become adapted quickly to wa-

Table 5. Problems in achieving the potential shown by minor fruit crops in Southeast Asia (after Menini, 1991) and in fighting rural poverty with forestry programs (after Jordan, 1988).

1) There are very few well-defined cultivars. The possibilities of selecting and eventually breeding superior clones have not been fully exploited in most producing areas. Some trees damage crops, others help them.

2) Propagation techniques have either not been standardized or the standard methods are not followed in the commercial propagation of plants. Adequate quantities of vegetatively propagated plants for regional expansion are not available.

3) Agro-techniques and management methods are very poor, resulting in low yields and quality. Not enough economic benefits are accrued from large plantations. "Middlemen" buy trees from large plantations and leave rural farmers with little or nothing.

4) Postharvest management practices tend to be empirical and inadequate.

5) In certain countries, specialized technical human resources are not available for research and development.

6) Farmers know how to grow trees, but not many entrepreneurs are interested in learning their methods.

7) Money and food to help plant trees is acceptable, but what is really needed is education and training.

8) Training must be practical and respect local know-how. The preference is for native trees. They grow well, produce dyes, medicine, nuts, fruit, and other things that are very useful.

9) Farmers and growers know that they can sell their goods, but it is difficult for them to run a business. There are labor problems and decisions on how to set prices and handle money.

10) Projects should start small and grow as things get better. extension advisors should help in project improvements. tercress and cruciferous vegetables treated with a biopesticide from Bacillus thuringiensis (Bt) (Fox, 1991; Norman, 1991). As yet, no Bt-producing plant is being marketed.

Other early results show that genetically engineered rhizobial strains, when released into the environment, will not compete successfully for nodule formation where indigenous rhizobia are well-established (Glover, 1988). This has been reaffirmed for a genetically manipulated variety of oil-seed rape (Cherfas, 1991). These plants do not outgrow their competitors in the wild, nor do they pass on genes to other species.

The adaptive plasticity of insects also holds true for diseases, and makes the deployment of woody perennials that are insect- and disease-resistant more suspect. Many pest life cycles are traversed over a single rotation in the production cycles of forest and fruit trees (e.g., walnut, conifers, Eucalyptus), so that special integrated strategies still need to be developed for pest control, and then proven as reliable.

The costs to grow a transgenic crop (e.g., cotton) and its worth to the mill are major considerations. Recent field trials have shown that fibers from two transgenic sources protected by a gene for Bt were sufficiently coarse to reduce their economic value. The fibers from transgenic plants had, however, good fiber length and elasticity and had stronger fiber (De Quattro, 1991). Researchers nowrecognize that other strategies are needed to keep insects from developing resistance to Bt. Among these is the introduction of genes that express other insecticidal proteins for use with Bt. For minor fruit crops in Southeast Asia, Menini (1991) has identified problems that are barriers to achieving their commercial potential (Table 5). Most of these problems can be overcome with traditional horticultural practices.

Accountability in technology transfer may be based arbitrarily on events categorized as: incidental-i.e., with no consequences; accidental-leading to issues of containment; unintentional-with requirements for a special case-by-case assessment; and deliberate-where release into the market is prohibited unless a special permit is granted. Quality control and assurance, certification, insurance, licensing and pricing policies, and special marketing strategies that protect the environment together can provide consumer protection and enhance the current standards for environmental health and safety. A major lesson of the Rio and Stockholm conferences on the global environment is that, in practice, the solutions to most environmental problems lie in the political and economic domains (Zuckerman, 1992).

Biotechnology has to solve convincingly 
a complex of extremely difficult industrial, social, ethical, economic, and political problems before it can begin to make rapid headway with protected applications to the longerlived horticultural crops in any society in a fully accountable way. It also has to deal with the "biosphere of our inheritance" and the "technosphere of our creation," which are out of balance and potentially in deep conflict (Ward and Dubos, 1973).

\section{Shared risks and cooperation}

Developing countries are considered by many as "rich countries inhabited by the poor." The consequences of the suboptimal use of local and diverse genetic resources often are found in faulty strategies, usually aimed at short-term benefits for a fortunate few. A list of risk factors for investing in biotechnology is given in Table 6. A more-detailed evaluation of the benefits and risks of genetic engineering in agriculture has been presented by Pimental et al. (1989).

Swaminathan (1989) argues that there is a need for: 1) a realistic assessment of the potentials and limitations of biotechnology, and 2) greater interactions between public and private sectors. In Asia, cooperation and the sharing of risks should be oriented towards appropriate land-use, resource planning, growth, promotion of ecological and job security, trends in international trade, and protection of patents and intellectual property. U.S. cooperation should not be restricted to the least-developed countries, but must extend to middle-income countries (Speth, 1992).

At the planning level, cooperation among international clients will not be are packaging ofpublic-private cooperation (Fig. 2). It will involve coordinated investment and dynamic interactions among all partners, as evidenced by Japanese activities in biotechnology (Brock, 1989). Cooperation requires: 1) the evolution of a strong coalition among government, business, and growers within regulations and based on stable socioeconomic political situations; 2) the establishment of viable forms of matrix management to deal with consensus and conflict for more widely accepted policy decisions; 3 ) the use of modern management methods to enable compromise and constructive reconciliation with all major players in industry, government, academia, the impacted public, and non-government organizations. The outcome often depends on "who wins" and "who loses" in international cooperation.

\section{International cooperation}

The United States has gained considerable insight on genetic diversity from re-
Table 6. Investment risk factors for biotechnology based on the existing situation, the potential for economic change, and the potential for sociopolitical change in countries with developing economies.

1) Identifiable, sustainable, and balanced production and utilization cycles. Benefits accrue to communities through reduced soil erosion, increased fuelwood, better agroforest protection, security of tenure, and access to germplasm reserves for industry expansion. The introduction of genetically engineered plants will have to face poor soil, product acceptability, and integration with existing intercropping strategies. Novel goods and services may force changes faster than politically feasible.

2) Nationalism as a sense of loyalty and devotion that promotes cultural and environmental interests at the expense of other nations or races.

3) Corruption, especially where bureaucrats earn lowest salaries and must supplement their official incomes to sustain a life style perceived to be in-line with their official positions. Harassment of villagers.

4) Prevalence of cartels and state-owned companies that discourage competition and introduce "hidden charges."

5) Instability of foreign-exchange rates. Lack of availability of hard currency. Understanding capitalistic business practices.

6) Red tape and bureaucracy that are unresponsive and unpredictable. No shelter for "infant industries" from foreign competition. Top-down approaches to planning that excludes villagers and non-governmental organizations.

7) Government attitude towards foreign investment. Banking provisions to cover risks of loan losses. Attitudes toward a sustainable balance of payments.

8) Openness of the trading system. Rate of import growth, export subsidies, access to the sea, agreements on trade and tariffs.

9) Protection offered for intellectual property and germplasm resources. Dependence on international agencies for protection.

10) Physical infrastructure to sustain the domestic market. Availability of energy, power supply, water, land, problem solving from local universities, fights over farm support.

11) Internal communications and transportation links. Roads, phones, telecommunications that cause problems in product distribution.

12) Labor force quality in terms of cost, availability, housing, education, and potential for human resource development. Role of women in management. Drug trafficking.

13) Potential for disruptive labor unrest among skilled and unskilled labor. Extent of unionism.

14) Potential for social unrest or progress as a function of poverty, quality of life, concentration of wealth, environmental quality, and soaring food costs.

15) Risks ofdisruptive political change that prevents systematic reforms to promote balanced investment and development. Size of armies in the region that remove resources from social and economic programs. Regional demilitarization.

search conducted in developing countries. In forestry and agroforestry, foreign research has been growing at a rapid rate. Gregersen et al. (1989) have suggested that U.S. scientists could: 1) increase efforts to tap foreign sources of information, 2) analyze systematically the current level of foreign involvement by U.S. institutions, to suggest changes in policy; and 3) influence high-level decisionmakers in government and industry regarding the costs and benefits arising from interactions between foreign and domestic researchers (see Wittwer, 1985).

Biotechnology also has appeared on the agenda of the United Nations Conference on Environment and Development in June 1992. The conference has recommended to governments and international organizations how 


Tates of many
U.S. horticulture
departments will
work at some
time during their
career for a firm
or organization
that bas interests
in these devel-
oping countries.

to alleviate environmental damage caused by human activities, and how to prevent future damage while allowing the economic development of poorer nations (Zuckerman, 1992). International cooperation is seen mainly to help countries with emerging economies to resolve constraints in the production of many tropical commodities and maintain their competitive position in international markets (see Shand, 1993). To this must be added new opportunities created in eastern Europe and by the formation of the Russian Federation and Confederation of Independent States. At present, progress is blocked by ethnic tensions, potential open conflicts, open wars, and national self-determination.

The graduates of many U.S. horticulture departments will work at some time during their career for a firm or organization that has interests in these developing countries. Graduates will face the issues that we and others have raised. This suggests the need for stronger connections with business schools and greater internationalization of domestic horticultural departments (Fretz, 1991), for priority-setting, and for exchanges for students and faculty in relation to the more specific tasks facing the transfer of technology to developing countries (Toenniessen, 1992). The development of a supportive, infrastructure for technology transfer and assessment in horticulture should involve transdisciplinary strategies and cooperative commercial ventures with public and private support aimed at countries with developing economies. This infrastructure should take into account the impact of global changes, food and nutrition, public health, urbanization, population growth, industrial development, scientific progress, education, and institutional changes (see Berry, 1992).

\section{Acknowledgements}

We thank Martina McGloughlin (Office of Biotechnology, Univ. of California) for suggestions on the preparation of this manuscript, to M.E. Austin (Dept. of Horticulture, Univ. of Georgia) for comments, and to contributors to the 1992 ASHS Workshop, "The Need for a Strategic Approach to Integrate Biotechnology into Developing Countries," chaired by Dr. Z.E. Abdel-Al, where this paper was presented initially.

\section{Literature Cited}

Amato, I. 1992. Chemists vie to make taxol. Science 256:311.

Anderson, C. 1991. U.S. patent application stirs up gene hunters. News. Nature (London) 353:485486.
Bakewell, D. 1992. New company to target technology transfer. Nature (London) 356:275.

Barton, J.H. 1989. Legal trends and agricultural biotechnology: Effects on developing countries. Trends Biotechnol. 7:264-268.

Berry, N. 1992. Forum on global change. Sigma Xi. Research Triangle Park, N.C. [Cited in: Amer. Scientist, March-April, p. 205-208.]

Bialy, H. 1991. From the green to the gene revolution: Biotechnology and the international centers. Bio/Technology 9:900.

Borman, S. 1991. Scientists mobilize to increase supply of anticancer drug taxol. Chem. Eng. News, 2 Sept. 11-18.

Brock, M.V. 1989. Biotechnology in Japan. Routledge, New York.

Butts, E.R. 1987. A review of biotech regulations involving plants. Genetic Eng. News, 24 Feb. p. 24-25.

Carlson, W.H. 1992. The need for strategic management in floriculture. HortScience 27:99. (Abstr.)

Chabner, B.A. 1991. Taxol, a test for technology transfer. Bio/Technology 9:1012.

Cherfas, J. 1991. Transgenic crops get a test in the wild. Science 251:878.

Cometta, S. 1989. Strategic considerations for the biotechnology business to the year 2000. Arzneimittelforschung 39:929-934.

De Quattro, J. 1991. Transgenic cotton scores knockout against worms. ARS/USDA 39:22-25.

Dibner, M.D. 1991. Tracking trends in U.S. biotechnology. Bio/Technology 9:1334-1337.

Durzan, D.J. 1991. Improving tree growth and quality through biotechnology. Kemira Kemi 18:192-199.

Faust, M. 1986. Priority areas for horticultural science. ASHS Nwslt. 2:(1)1.

Flam, F. 1993. Congress may reform biotech patenting. Science 259:898.

Fox, J.L. 1991. Bt resistance prompts early planning. Bio/Technology 9:1319-1313.

Fretz, T.A. 1991. Internationalization of horticulture departments. ASHS Nwslt. 7:3.

Gerhold, H.D., E.J. Schreiner, R.E. McDermott, and J.A. Winlesk. 1966. Breeding pest-resistant trees. Pergamon, New York.

Glass, D.J. and J. Lindemann. 1992. Biotechnology in agriculture: The next decade. Decision Resources, inc., Burlington, Mass.

Glover, S. 1988. Dos and don'ts of genetic release. Nature (London) 333:297-298.

Gould, F. 1991. The evolutionary potential of crop pests. Amer. Scientist 79:496-507.

Gregersen, H., J. Haygreen, S. Sindelar, and P. Jakes. 1989. U.S. gains from foreign forestry re- 
search. J. For. Feb. p. 21-26.

Grierson, W. 1991. HortTechnology and the developing countries. HortTechnology 1(1):136-137.

Hobbelink, H. 1989. Biorevolution and biotechnologies: The role of INGOs. Transnational Assns. 3:137-149.

Hoyle, K. 1993. Shelved by Campbell, Calgene retreats at FDA. Bio/Technology 11:152-153.

Jordan, C.B.K. 1988. Forestry program fights rural poverty. J. For. May. p. 39-41.

Kloppenburg, J.R., Jr. 1988. Seeds and sovereignty. The use and control of plant genetic resources. Duke Univ. Press, Durham, N.C.

Knight, P. 1989. Engineered fruit and vegetable crops. Bio/Technology 7:1233-1237.

Krugman, P.A. 1991. Myths and realities of U.S. competitiveness. Science 254:811-815.

Kuttner, R. 1992. Without ground rules, it will be open season on open markets. Business Week, 16 Mar. p. 22.

Lesser, W. 1990. An overview of intellectual property systems, p. 5-15. In: W.E. Siebeck (ed.). Strengthening protection of intellectual property in developing countries. World Bank Discussion Paper 112.

Marshall, E. 1991. The patent game: Raising the ante. Science 253:20-24.

Menini, U.G. 1991. Potential and issues for collaborative action on tropical fruit research and development. Chron. Hort. 31:38-39.

Nature. 1992. Ducking big problems is cowardly. Nature (London) 358:175-176.

Nestle, M. 1992. Food biotechnology: Truth in advertising. Bio/Technology 10:1056.

Norman, C. 1991. Moths take the field against biopesticide. Science 254:646.

Office of Technology Assessment. 1991. Biotechnology in a global economy. U.S. Congress, Office of Technology Assessment. U.S. Government Printing Office, Washington, D.C. OTA-BA-494,

Pacific Coast Nurseryman and Garden Supply Dealer. 1991a. AAN President Campbell outlines challenges to industry gleaned from view research data. Pacific Coast Nurseryman and Garden Supply Dealer 50:36-38.

Persley, G.J. 1990a. Beyond Mendel's garden: Biotechnology in the service of world agriculture. CAB. International, Wallingford, Oxon. ISBN 085198-682-X.

Persley, G.J. (ed.). 1990b. Agricultural biotechnology: Opportunities for international development. CAB. International, Wallingford, Oxon. ISBN 085198-643-9.
Pharmaceutical Manufacturers Association. $1991 b$. Pharmaceutical Manufacturers Assn., Washington, D.C. Communications Div. Bul.

Pimental, D., M.S. Hunter, J.A. La Gro, R.A. Efroymson, J.C. Landers, F.T. Mervis, C.A. McCarthy, and A.E. Boyd. 1989. Benefits and risks of genetic engineering in agriculture. Bioscience 39:606-612.

Salquist, R.H. 1987. The future of biotechnology in agriculture. Genetic Eng. News 7:4.

Shand, H. 1993. Agbio and Third World development. Editorial 2003. Bio/Technology 11:8-13.

Siebeck, W. (ed.). 1990. Strengthening protection ofintellectual property in developing countries. A survey of the literature. World Bank, Washington, D.C. Discussion Paper 112.

Simpson-Dolbeare, $R$. 1991. Patents and trademarks. The benefits and pitfalls. Amer. Nursery man 173:103-109.

Speth, J.G. 1992. A new U.S. program for international development and the global environment. World Resources Inst. Issues and Ideas, March, Washington, D.C.

Sterling, J 1992. USDA seeks easing of field test requirements. Genetic Engineering News, 15 Nov. p. 16.

Swaminathan, M.S. 1989. Biotechnology and a better common present. Regional Seminar on Public Policy Implications of Biotechnology for Asian Agriculture. 6-8 Mar. 1989, New Delhi, Asian and Pacific Development Center.

Swinbanks, D. 1992. Japanese researchers rule out gene patents. Nature (London) 56:181.

Toenniessen, G. 1992. Building plant science research capacity in developing countries. The Plant Cell. Jan. p. 5-6.

Trigo, E.J. and W. Jaffe. 1990. Biosafety regulations in developing countries. Inter-American Inst. for Cooperation in Agriculture, San Jos, Costa Rica.

Ward, B. and R. Dubos. 1973. Only one Earth. Pelican, London.

Wittwer, S.H. 1985. The new horticulture-programming the future. HortScience 20:815-821.

Vietmeyer, N.D. 1986. Lesser-known plants of potential use in agriculture and forestry. Science 232:1379-1384.

Zobel, B. 1992. Vegetative propagation in production forestry. J. For. Apr. p. 29-33.

Zuckerman, Lord. 1992. Between Stockholm and Rio. Nature (London) 358:273-276. 